\title{
A Review on Microbial Enzymes, Synthesis, Biological Role, Current Applications and Future Perspectives
}

\author{
Ishrat Naureen ${ }^{1}$, Muhammad Jawad Bashir², Waheed Ahmed ${ }^{3}$, Syed Abrar Hussain ${ }^{2}$, Muhammad Hasher Naveed ${ }^{4}$ \\ Aurangzeb Ijaz ${ }^{5 *}$, Faisal Nadeem ${ }^{6}$ \\ ${ }^{1}$ Madinah Teaching Hospital, The University of Faisalabad, Pakistan \\ ${ }^{2}$ Institute of Microbiology, University of Agriculture, Faisalabad, Pakistan \\ ${ }^{3}$ Department of Parasitology \& Microbiology, PMAS arid Agriculture University Rawalpindi, Shamsabad, Muree ‘Road, Punjab ‘ \\ Rawalpindi, 46000, Pakistan \\ ${ }^{4}$ Department of Entomology, University of Agriculture Faisalabad, Pakistan \\ ${ }^{5}$ Department of Microbiology, Government College University, Faisalabad, Pakistan \\ ${ }^{6}$ Centre of Agricultural Biochemistry and Biotechnology (CABB), University of Agriculture Faisalabad, Pakistan
}

*Corresponding author: Aurangzeb Ijaz

\section{Abstract}

Increased uses of microbial enzymes in cheese processing are largely responsible for the use of enzymes in dairy industry, which is the next largest application industry followed by the beverages industry. Microbial enzymes such as fructosyltransferase, laccases, amylases, lipase, and cholesterol oxidase, as well as their potential applications in various industries. GUS in the form of $\beta$-glucuronidases acting as main gut enzyme have been sued in the pharmaceutical and clinical trials for testing the drugs toxicity prior their use in the human body. Amylase is the most important microbial enzyme that involved in the digestion of starch into small molecules of sugars. Amylase obtained from microorganisms usually less expensive and catalyzed the breakdown of starch in effective ways while the amylase obtained form plants as well as other animals required lots of chemicals and other microbial process for their separation, purification as well as their characterization. Submerged fermentation is the cultivation of microorganisms in liquid nutrient broth. Industrial enzymes can be produced using this process. In a batch process, all nutrients are provided at the beginning of the cultivation, without adding any more in the subsequent bioprocess.

Keywords: Microbes, Enzymes, amylase, applications, batch fermentation.

Copyright $(\mathcal{C} 2021$ The Author(s): This is an open-access article distributed under the terms of the Creative Commons Attribution 4.0 International License (CC BY-NC 4.0) which permits unrestricted use, distribution, and reproduction in any medium for non-commercial use provided the original author and source are credited.

\section{INTRODUCTION}

There are different microbes that have used been sued in the industrial processes because they contain enzymes that speed up the chemical reactions. The presence of enzymes in right composition makes them ideal candidate for the preparation of different products utilized by human [1-3]. They have been sued in the different ways such as foods, detergents, in medicines for the preparation of synthetic drugs also for energy reservoirs. Their utilization in industry carried in different ways but in appropriate manner. They are used due to low cost as compared to their species of the viruses. They are less producing toxins in laboratory investigation due to environment friendly. Hence, their use in the different productions of synesthetic materials made to improve the economy at large scale $[4,5]$.
The application of enzymes in food industry is segmented into different sectors, such as baking, dairy, juice production and brewing. Worldwide, microbial enzymes are efficiently utilized in bakery as the principal application market in food industry to improve dough stability, crumb softness and structure, and shelf life of products. Increased uses of microbial enzymes in cheese processing are largely responsible for the use of enzymes in dairy industry, which is the next largest application industry followed by the beverages industry [6].

"Microbial Enzymes: Roles and applications in industry" offers an essential update on the field of microbial biotechnology, and presents the latest information on a range of microbial enzymes such as fructosyltransferase, laccases, amylases, lipase, and 
cholesterol oxidase, as well as their potential applications in various industries. Production and optimisation technologies for several industrially relevant microbial enzymes are also addressed [7, 8].

\section{Role of Beta-glucuronidases}

GUS in the form of $\beta$-glucuronidases acting as main gut enzyme have been sued in the pharmaceutical and clinical trials for testing the drugs toxicity prior their use in the human body. Sometimes, drug releases toxic chemicals that damage the other parts of the body such as liver [9]. GUS biochemically binds to that toxic chemicals and assist in the toxicity caused by specific drugs either used for the treatment of specific disease. The gut of the human contains a variety of microbes for assisting in process of digestion. Actually, gut acting as main target of microbes to check the action of different drugs and other products used in clinical trials $[10,11]$.

Microbial enzymes possess different characteristics in response to temperature, $\mathrm{pH}$ and stability as compared to the other organisms. These characteristics inculcated the thermophiles. Some bacteria are thermosatble due to presence of special enzymes present in them also showing different functions in response to temperature relatively at high temperature. This property of the thermo stabile enzymes leads to breakdown of the large products at high temperature but also enhance the speed of reaction at large level due to active nature of enzymes that showing stability at most high temperature. Sometime, other species of the bacteria showing sensitivity to $\mathrm{pH}$ and hence changes in $\mathrm{pH}$ receptively leads to usability of enzymes but most of bacteria working under specific conditions of temperate level and $\mathrm{pH}$ [12-14].

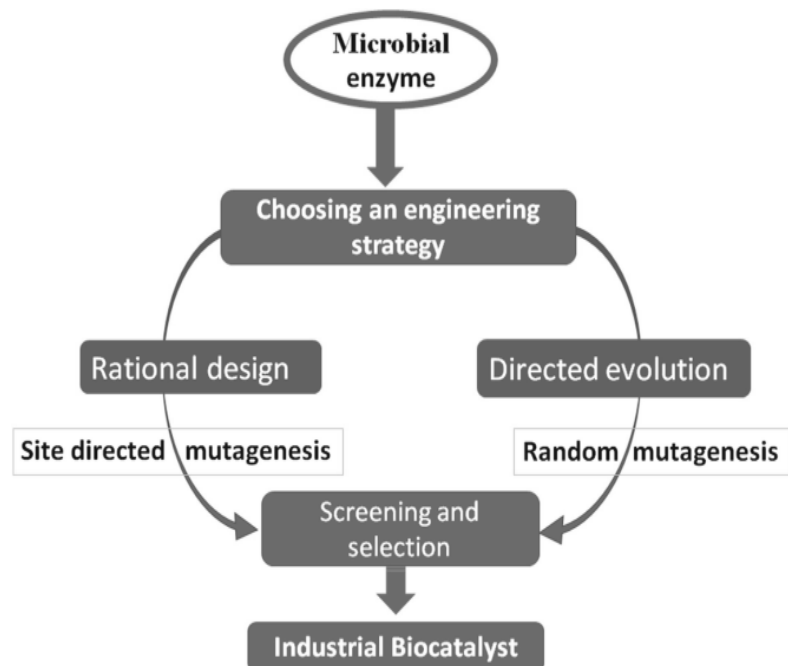

Fig-1: Shows the role of microbial enzymes in different industrial processes

\section{Role of Amylase}

Amylase is the most important microbial enzyme that involved in the digestion of starch into small molecules of sugars. These molecules further available to the other cells for cellular processes and other mechanism necessary at molecular level. This enzymes is particularly present in the human and their source is the saliva that biochemically helps to breakdown and ultimately digestion of large molecules. This enzymes helps in food digestion by acting on the food particles for their breakdown. Amylase also present in the pancreas for the digesting of starch to disaccharides that ultimately converted to the simple sugars for maintaining the body also provides energy to cellular mechanism [15-17].

Amylase obtained from microorganisms usually less expensive and catalyzed the breakdown of starch in effective ways while the amylase obtained from plants as well as other animals required lots of chemicals and other microbial process for their separation, purification as well as their characterization. Most of the potential bacteria also producing amaylase that increase the ceremony of the food indsiusyries also pharmaceutical industries. This enzyme particlaury replaced the chemical hydrolysis of expensive chemicals that required lots of energy and high costs [18-20].

\section{Role of Keratinases}

Keratinase is the specific proteomic based specific protein that made up of specific type of amino acids which involved to breakdown the insoluble keratins due to inactive nature. This proteins has stable structure and also catalyzed the breakdown of variety of other proteins in different ways. Their important lies in the field of medicals especially for the preparation of different pharmaceuticals products and artificial medical products. Hence, plays significant roles in the medical industry [21, 22].

Keratinase is generally found in different parts of body as a main source of structural sources due to their stable structure. It is generally found the outer parts of the body such as skin and different parts of nails. It functions included the breakdown of the waste product produced in by relaxing from the particular source. It also acts a source of source of supplementation of nitrogen for the plants by supply the larger supplying of nitrogen due to presence of amino acids that are responsible for thrower stable structure. It is a fibre like proteins that structure has been characterized for their isolation and role in different ways. This proteins also acts as structural proteins marinating the structure of wool also balance the amino acids to keep them in right place and also positioning of amino acids [23, 24].

\section{Role of Microbial Proteases}

Microbial protease gained great importance in the biochemical industry to synthesize the variety of compounds. Some species of the bacteria such as Bacillus are actively involved in the production of 
mucosal protease for the degradation of larger compounds. These species of the bacteria mostly active to perform biological functions at normal temperature and $\mathrm{pH}$. Some changes in structure leads to instability the of microbial protease. It ultimately disrupt the statured of amino acids that making the statured and marinating satiability of microbial peptides. There is need to edit the genes in some species of the bacteria at the molecular level [25-27].

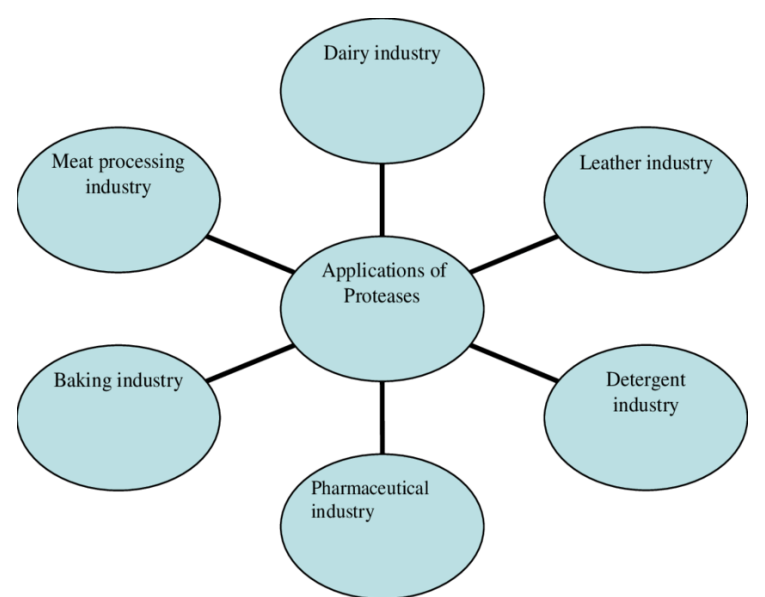

Fig-2: Shows the different applications of microbial proteases
Some proteases obtained from the microbes that used to breakdown the large number of compounds into smaller substances for their use to make new material in industries. The enzymes that obtained form the industries have great importance in industries. The products that obtained form the microbial proteases are pharmaceutical, food based and feed that animals take in the form of raw material. Microbial proteases are important for the gradual breakdown of stable compounds that have been employed in molecular and cellular processes [28-30].

\section{Synthesis of Microbial enzymes Submerged fermentation}

Submerged fermentation is the cultivation of microorganisms in liquid nutrient broth. Industrial enzymes can be produced using this process. This involves growing carefully selected microorganisms (bacteria and fungi) in closed vessels containing a rich broth of nutrients (the fermentation medium) and a high concentration of oxygen. As the microorganisms break down the nutrients, they release the desired enzymes into solution [31].

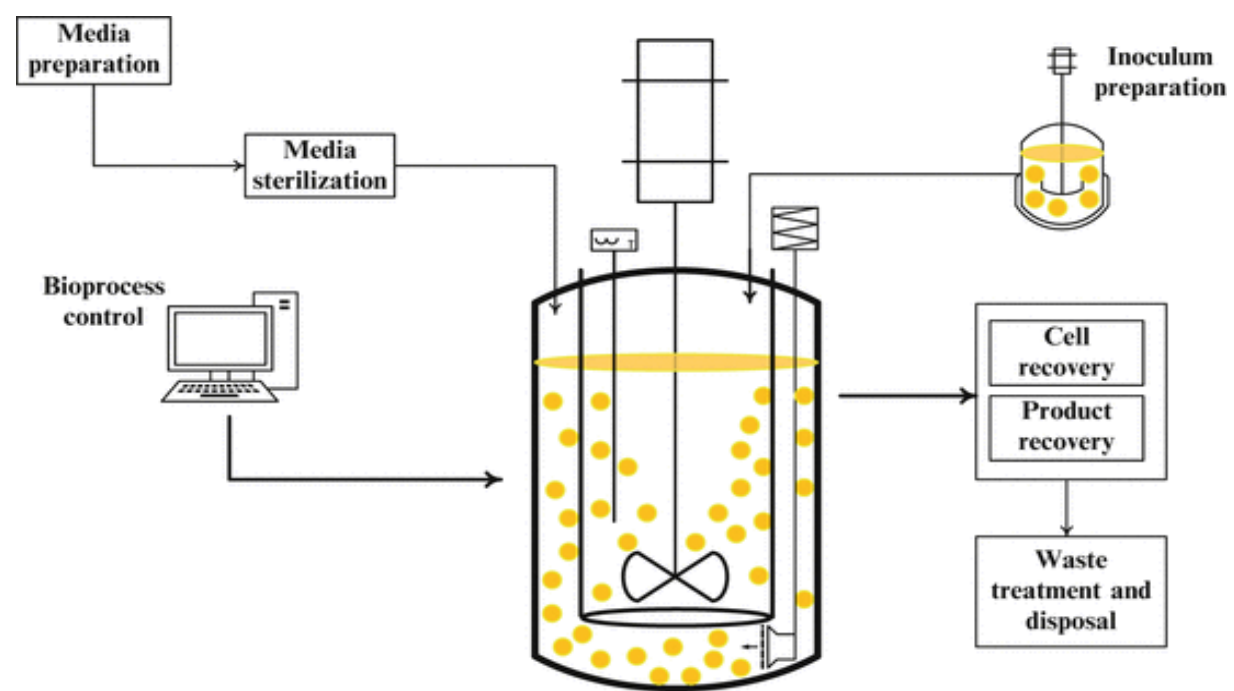

Fig-3: Shows principle of submerged fermenting for the production of enzymes

\section{In continuous fermentation}

Fresh medium is continuously added to the fermentor, while used medium and cells are harvested at the same time. Consumed nutrients are replaced and toxic metabolites are removed from the culture. When addition and removal are at the same rate, the culture volume stays constant [32].

\section{Batch fermentation}

In a batch process, all nutrients are provided at the beginning of the cultivation, without adding any more in the subsequent bioprocess. During the entire bioprocess, no additional nutrients are added just control elements such as gases, acids and bases; it is a closed system. The bioprocess then lasts until the nutrients are consumed. This strategy is suitable for rapid experiments such as strain characterization or the optimization of nutrient medium. The disadvantage of this convenient method is that the biomass and product yields are limited. Since the carbon source and/or oxygen transfer are usually the limiting factor, the microorganisms are not in the exponential growth phase for a long time [33, 34]. 


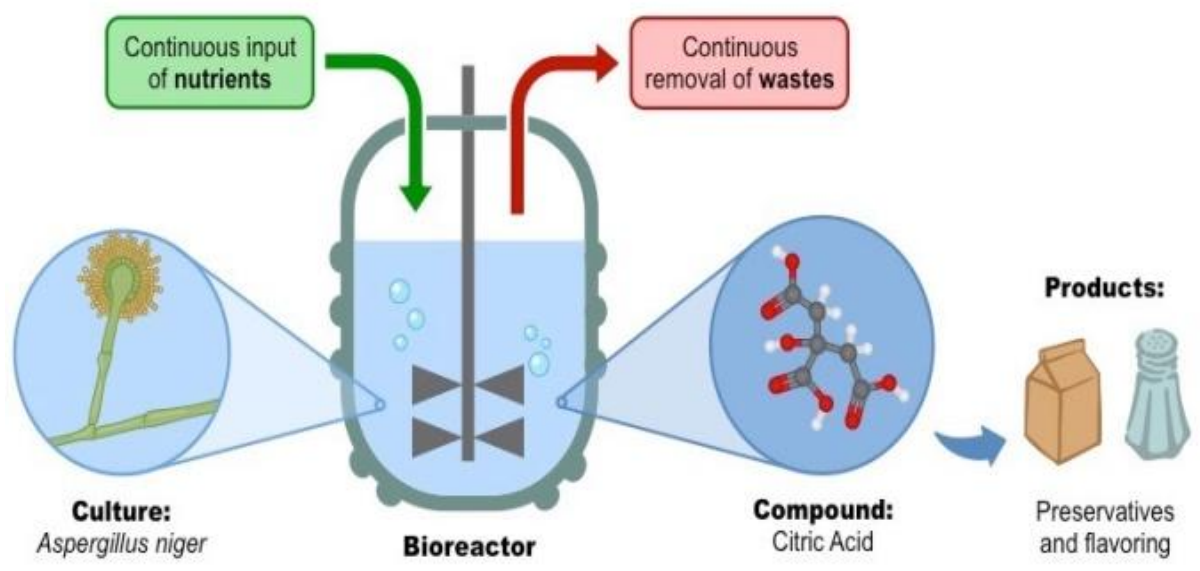

Fig-4: Shows fermentation principles for the production of microbial enzymes

\section{CONCLUSION}

Different microbial enzymes have been used for different processes in medical as well as industries. Increased uses of microbial enzymes in cheese processing are largely responsible for the use of enzymes in dairy industry, which is the next largest application industry followed by the beverages industry. Microbial enzymes possess different characteristics in response to temperature, $\mathrm{pH}$ and stability as compared to the other organisms.

\section{REFERENCES}

1. Shahid, A., Ali, S., Zahra, T., Raza, M., Shahid, A., Saeed, M. U., \& Javaid, F. Influence of Microbes in Progression of Cancer and DNA Damaging Effects.

2. Iftikhar, A., Shahid, A., Shah, S. S., Ali, S., Raza, M., Ali, E., \& Umbreen, S. Antimicrobial Activities of Selected Medicinal Plant with Potential Role of Chemical Compounds.

3. Qamar, M., Mustafa, G. A., Tariq, S., Rafeeq, H., Rafiq, M., Naqvi, W. Z., ... \& Kanwal, T. Novel Methods for Detection of Biological Samples, Current Direction and Future Perspectives.

4. Naeem, M., Hayat, M., Qamar, S. A., Mehmood, T., Munir, A., Ahmad, G., ... \& Hussain, A. (2019). Risk factors, genetic mutations and prevention of breast cancer. Int. J. Biosci, 14(4), 492-496.

5. Shafiq, S., Adeel, M., Raza, H., Iqbal, R., Ahmad, Z., Naeem, M., ... \& Azmi, U. R. (2019). Effects of Foliar Application of Selenium in Maize (Zea Mays L.) under Cadmium Toxicity. In Biological Forum-An International Journal (Vol. 11, No. 2, pp. 27-37).

6. Ahmad, I., Khan, S., Naeem, M., Hayat, M., Azmi, U. R., Ahmed, S., ... \& Irfan, M. (2019). Molecular Identification of Ten Palm Species using DNA Fingerprinting. Int. J. Pure App. Biosci, 7(1), 4651.

7. Usman, G., Muhammad, N., Hamza, R., Usman, I., Ayesha, A., Saqib, U., ... \& Fatima, Q. (2019). A Novel Approach towards Nutraceuticals and
Biomedical Applications. Scholars International Journal of Biochemistry, 2(10), 245-252.

8. Tahir, M. F., Ali, S., Noman, M., \& Goher, M. A Novel Approach towards the Potential Effects of Chlorpyrifos on Testicular Biochemistry and Physiology of Male Sprague Dawely Rats.

9. Naeem, M., Ali, J., Hassan, M. Z., Arshad, B., Rao, M. H. I., Sarmad, M. S. K., ... \&amp; Hassan, M. U. (2019). Novel Approach towards DNA Barcoding as a Tool in Molecular Biologyand Biological Activities of Cyclotides with Particular Emphasizes at Molecular Level. In Biological Forum-An International Journal, 11(2), 83-96.

10. Naeem, A., Saddique, S., \& Chand, S. A. (2019). Advancement and Future Directions towards Herbal Treatment for Various Diseases.

11. Schmidt, T. S., Hayward, M. R., Coelho, L. P., Li, S. S., Costea, P. I., Voigt, A. Y., ... \& Bork, P. (2019). Extensive transmission of microbes along the gastrointestinal tract. Elife, 8, e42693.

12. Wehrs, M., Tanjore, D., Eng, T., Lievense, J., Pray, T. R., \& Mukhopadhyay, A. (2019). Engineering robust production microbes for large-scale cultivation. Trends in microbiology, 27(6), 524537.

13. White, J. F., Kingsley, K. L., Zhang, Q., Verma, R., Obi, N., Dvinskikh, S., ... \& Kowalski, K. P. (2019). Endophytic microbes and their potential applications in crop management. Pest management science, 75(10), 2558-2565.

14. Naeem, M., Ashraf, A., Safdar, H. M. Z., Khan, M. Q., Rehman, S. U., Iqbal, R., \& Ahmad, G. (2020). Biochemical changes in patients with chronic kidney failure in relation to complete blood count and anemia. IJB, 16(1), 267-271

15. Rocha, I., Ma, Y., Souza-Alonso, P., Vosátka, M., Freitas, H., \& Oliveira, R. S. (2019). Seed coating: a tool for delivering beneficial microbes to agricultural crops. Frontiers in plant science, 10, 1357.

16. Thomashow, L. S., Kwak, Y. S., \& Weller, D. M. (2019). Root- associated microbes in sustainable 
Ishrat Naureen et al., Sch Bull, Mar, 2021; 7(3): 44-48

agriculture: models, metabolites and mechanisms. Pest management science, 75(9), 2360-2367.

17. Harman, G. E., \& Uphoff, N. (2019). Symbiotic root-endophytic soil microbes improve crop productivity and provide environmental benefits. Scientifica, 2019.

18. Naeem, M., Hussain, A., Azmi, U. R., Maqsood, S., Imtiaz, U., Ali, H., ... \& Ghani, U. (2019). Comparative Anatomical Studies of Epidermis with Different Stomatal Patterns in Some Selected Plants Using Compound Light Microscopy. International Journal of Scientific and Research Publications, 9(10), 375-380.

19. Ahsan, M., Aslam, M., Akhtar, M. A., Azmi, U. R., Naeem, M., Murtaza, G., ... \& Shafiq, S. (2019). Effect of inoculation of three rhizobial strains on maize hybrids. Journal of Biodiversity and Environmental Sciences, 14(6), 168-177.

20. Hazafa, A., Batool, A., Ahmad, S., Amjad, M., Chaudhry, S. N., Asad, J., ... \& Ghani, U. (2020). Humanin: A mitochondrial-derived peptide in the treatment of apoptosis-related diseases. Life Sciences, Volume 264, 2021, 118679.

21. Khan, S., Abbas, A., Ali, I., Arshad, R., Tareen, M. B. K., \& Shah, M. I. (2019). Prevalence of overweight and obesity and lifestyle assessment among school-going children of Multan, Pakistan.

22. Rafeeq, H., Ahmad, S., Tareen, M. B. K., Shahzad, K. A., Bashir, A., Jabeen, R., ... \& Shehzadi, I. Biochemistry of Fat Soluble Vitamins, Sources, Biochemical Functions and Toxicity. Haya: The Saudi Journal of Life Sciences

23. Ghani, U., Naeem, M. Bukhari, S.S.H., Yar, G., Tariq, I., Siddique, S., Nawaz, H.A., Pal, Z.A.A., Nasim, F. and Bukhari, S.A.H. (2019). Prevalence and Risk Factors associated with Hepatitis B and Hepatitis $\mathrm{C}$ and their Correlation with Inflammatory Markers among Southern Region of Punjab. Biological Forum - An International Journal, 11(2): 136-143.

24. Muhammad Naeem, Umair Rasool Azmi,Sarmad Ahmad Qamar, Ahmad Munir, Tariq Mahmood, Muhammad Adeel Faryad. 2019. Reliable vaccine production by using Risk Based Bioengineering Strategies. 6th International Conference on "Sustainable Agriculture in Changing Climate: Strategies and Management. 261.

25. Rafeeq, H., Arshad, M. A., Amjad, S. F., Ullah, M. H., Muhammad, H., Imran, R. K., ... \& Ajmal, H.
Effect of Nickel on Different Physiological Parameters of Raphanus Sativus.

26. Rebolleda- Gómez, M., Forrester, N. J., Russell, A. L., Wei, N., Fetters, A. M., Stephens, J. D., \& Ashman, T. L. (2019). Gazing into the anthosphere: considering how microbes influence floral evolution. New Phytologist, 224(3), 1012-1020.

27. Bishehsari, F., \& Keshavarzian, A. (2019). Microbes help to track time. Science, 365(6460), 1379-1380.

28. Steensels, J., Gallone, B., Voordeckers, K., \& Verstrepen, K. J. (2019). Domestication of industrial microbes. Current biology, 29(10), R381R393.

29. Leventhal, G. E., Ackermann, M., \& Schiessl, K. T. (2019). Why microbes secrete molecules to modify their environment: the case of ironchelating siderophores. Journal of the Royal Society Interface, 16(150), 20180674.

30. Seferovic, M. D., Pace, R. M., Carroll, M., Belfort, B., Major, A. M., Chu, D. M., ... \& Aagaard, K. M. (2019). Visualization of microbes by $16 \mathrm{~S}$ in situ hybridization in term and preterm placentas without intraamniotic infection. American journal of obstetrics and gynecology, 221(2), 146-e1.

31. Yadav, A. N., Kour, D., Sharma, S., Sachan, S. G., Singh, B., Chauhan, V. S., ... \& Saxena, A. K. (2019). Psychrotrophic microbes: biodiversity, mechanisms of adaptation, and biotechnological implications in alleviation of cold stress in plants. In Plant growth promoting rhizobacteria for sustainable stress management (pp. 219-253). Springer, Singapore.

32. Bhushan, B., Singh, B. P., Saini, K., Kumari, M., Tomar, S. K., \& Mishra, V. (2019). Role of microbes, metabolites and effector compounds in host-microbiota interaction: a pharmacological outlook. Environmental Chemistry Letters, 17(4), 1801-1820.

33. Champagne-Jorgensen, K., Kunze, W. A., Forsythe, P., Bienenstock, J., \& Neufeld, K. A. M. (2019). Antibiotics and the nervous system: More than just the microbes?. Brain, behavior, and immunity, 77, 7-15.

34. Kumar, S., Sharma, S., Thakur, S., Mishra, T., Negi, P., Mishra, S., ... \& Yadav, A. N. (2019). Bioprospecting of microbes for biohydrogen production: current status and future challenges. Bioprocessing for Biomolecules Production, 443-471. 